\title{
Amplification of the human epidermal growth factor receptor 2 gene in differentiated thyroid cancer correlates with telomere shortening
}

\author{
YOSHIYUKI SUGISHITA ${ }^{1}$, MAKOTO KAMMORI ${ }^{1,2}$, OSAMU YAMADA ${ }^{4}$, STEVEN S.S. POON ${ }^{5}$, \\ MAKIO KOBAYASHI $^{6}$, NAOYOSHI ONODA ${ }^{7}$, KAZUKO YAMAZAKI ${ }^{1}$, TATSUYA FUKUMORI ${ }^{2}$, \\ KEI-ICHI YOSHIKAWA ${ }^{2}$, HIROYUKI ONOSE ${ }^{3}$, SHINNYA ISHII ${ }^{3}$, EMIKO YAMADA ${ }^{3}$ and TETSU YAMADA $^{1,2}$ \\ Departments of ${ }^{1}$ Clinical Pathology, ${ }^{2}$ Surgery and ${ }^{3}$ Internal Medicine, Kanaji Hospital, Kita-ku, \\ Tokyo 114-0015; ${ }^{4}$ Medical Research Institute, Tokyo Women's Medical University, Shinjuku-ku, \\ Tokyo 162-8666, Japan; ${ }^{5}$ Terry Fox Laboratory, British Columbia Cancer Research Center, Vancouver, \\ BC V5Z1L3, Canada; ${ }^{6}$ Department of Clinical Pathology, Mithuwadai General Hospital, Wakaba-ku, Chiba 264-0021; \\ ${ }^{7}$ Department of Surgical Oncology, Osaka City University Graduate School of Medicine, Abeno-ku, Osaka 545-8585, Japan
}

Received December 18, 2012; Accepted February 11, 2013

DOI: 10.3892/ijo.2013.1848

\begin{abstract}
The human epidermal growth factor receptor 2 (HER2) proto-oncogene plays an important role in the development and progression of breast and gastric cancer. Monitoring of the HER2 status and treatment with trastuzumab was performed initially in breast cancer, and subsequently in gastric cancer. However, the HER2 status of thyroid cancer remains unexplored. Telomere alteration and telomerase activity have been observed in most human cancers and are known to be a feature of malignancy. The aims of this study were to clarify the HER2 status of thyroid cancer and to examine any correlations to various characteristics of malignancy. We investigated 69 cases of differentiated thyroid cancers with reference to: i) telomere length as measured using tissue quantitative fluorescence in situ hybridization (Q-FISH), ii) expression of human telomerase reverse transcriptase (hTERT) as determined by immunohistochemistry (IHC), and iii) overexpression of the HER2 protein as determined by IHC and amplification of the HER 2 gene as determined by fluorescence in situ hybridization (FISH). The telomeres of thyroid cancers, especially follicular carcinomas, were significantly shorter compared to those of adjacent normal tissues. Positivity for hTERT expression and HER 2 amplification were observed in approximately 70 and $22 \%$ of thyroid cancers, respectively. Our data demonstrated that telomeres in HER2-positive cancers were significantly shorter compared
\end{abstract}

Correspondence to: Dr Makoto Kammori, Department of Surgery, Kanaji Hospital, 1-5-6 Nakazato, Kita-ku, Tokyo 114-0015, Japan E-mail: kammori@kanaji.jp

Key words: telomere, tissue quantitative fluorescence in situ hybridization, telomerase, human epidermal growth factor receptor 2/neu, differentiated thyroid cancer to those in HER2-negative cancers. These results suggest that highly malignant differentiated thyroid cancer can be detected by monitoring HER 2 status and telomere shortening, and that trastuzumab therapy may be effective for refractory thyroid cancer.

\section{Introduction}

Human epidermal growth factor receptor 2 (HER2), also known as erbB2 and HER2/neu, is a proto-oncogene located at 17q12-21.32, playing an important role in the development and progression of human tumors, most notably breast cancer. This gene encodes a $185-\mathrm{kDa}$ transmembrane protein with tyrosine kinase activity known to be involved in signal transduction during cell growth $(1,2)$. Amplification of the gene has been identified in approximately $25-30 \%$ of human breast tumors $(3,4)$. Amplification of HER2 and concomitant overexpression of the protein is considered to be an important biological marker of poor prognosis, more aggressive disease, and an increased risk of recurrence (3-5), as well as being a useful indicator of response to anti-HER2 therapy, for example using trastuzumab. To assess whether patients are likely to benefit from trastuzumab, monitoring of HER2 status has become routine practice using two techniques that are often used together: detection of gene amplification and protein overepression using fluorescence in situ hybridization (FISH) and immunohistochemistry (IHC), respectively.

Most studies have reported that the HER2 positivity rate in gastric cancer is about $15-25 \%$ (6-9), and that HER2 positivity in gastric cancer is associated with poorer prognosis, more aggressive disease and shorter survival (7,9-14). Trastuzumab treatment has been shown to be clearly beneficial for patients with gastric cancer showing HER2 gene amplification and/or protein overexpression (15). Breast cancer was the first malignancy for which HER2 gene amplification or protein overexpression was detected and trastuzumab therapy applied, and this was later extended to gastric cancer. However, no 
detailed study has yet investigated HER2 gene amplification and protein overexpression in thyroid cancer.

Telomeres, which are located at the ends of chromosomes, are composed of a repeated DNA sequence (TTAGGG) and specific binding proteins. These structures protect chromosome ends and prevent them from being recognized as DNA double-strand breaks (16). The telomere repeat sequence becomes shortened by each cell division, DNA damage due to oxidative stress or through changes in telomere-associated proteins $(17,18)$. It has been proposed that telomere shortening is an important biological factor involved in carcinogenesis, cell senescence, cell replication, cell immortality and aging (19-21). Thus, as a biological marker, telomere length reflects malignant potential, and might also be associated with genetic instability and the degree of malignancy risk (22). The enzyme telomerase is a reverse transcriptase that maintains chromosome ends by addition of the DNA sequence repeat TTAGGG to the end of a DNA strand. The enzyme is composed of a telomerase RNA component (TERC), and a protein component called human telomerase reverse transcriptase (hTERT), along with specific accessory proteins. The telomerase synthesizes the telomeric DNA, and counteracts progressive shortening of the telomere (23). Some cancers, including thyroid cancer (24), and their precursor lesions have been reported to show telomere shortening (25-29), telomerase activation (27) and expression of hTERT mRNA (30).

The aim of this study was to clarify whether HER 2 gene amplification and protein overexpression are detectable in differentiated thyroid cancer, and to investigate any correlations between HER 2 status and feature of malignancy such as telomere shortening or hTERT expression. For this purpose, we measured telomere lengths in thyroid cancer using quantitative fluorescence in situ hybridization (Q-FISH), which allowed us to estimate the telomere lengths of individual cells in each section. We examined the expression of hTERT and overexpression of HER 2 protein by IHC using an antihTERT polyclonal antibody and an anti-c-erbB2 monoclonal antibody, respectively. Furthermore, we performed FISH to detect amplification of the HER2 gene in differentiated thyroid cancer.

\section{Materials and methods}

Tissue specimens. We examined a total of 69 thyroid tumors, including 61 papillary carcinomas and 8 follicular carcinomas. All samples were collected after obtaining informed consent from the patients, who underwent thyroidectomy at the Kanaji Thyroid Hospital, Tokyo, Japan. Tumor and adjacent normal tissues were obtained from each patient and stored at $-80^{\circ} \mathrm{C}$ until fixation. The tissues were then fixed for $2 \mathrm{~h}$ in $10 \%$ buffered formalin solution and embedded in paraffin according to standard processing procedures. They were then sliced into sections $4 \mu \mathrm{m}$ thick for FISH and IHC analysis.

Tissue Q-FISH. Tissue Q-FISH was performed as described previously $(31,32)$. In brief, tissue sections were deparaffinized and treated with $0.2 \mathrm{~N} \mathrm{HCl}, 1 \mathrm{M}$ sodium thiocyanate at $80^{\circ} \mathrm{C}$, $1 \%$ pepsin at $37^{\circ} \mathrm{C}$, and $10 \mathrm{mg} / \mathrm{ml}$ RNase at $37^{\circ} \mathrm{C}$. A peptide nucleic acid (PNA) telomere probe conjugated to $\mathrm{Cy} 3$ (telo $\mathrm{C}$ Cy3 probe: 5'-CCCTAACCCTAACCCTAA-3', Fasmac,
Kanagawa, Japan) and a PNA centromere probe conjugated to fluorescein isothiocyanate (FITC) (Cenp 1 probe: 5'-CTTCGTT GGAAACGGGT-3', Fasmac) were applied to each section. The nuclei were stained with 4',6-diamidino-2-phenylindole (DAPI) (Sigma-Aldrich, St. Louis, MO).

FISH images were recorded by a CCD camera attached to an epifluorescence microscope (Eclipse 90i, Nikon, Tokyo, Japan) equipped with a triple band-pass filter set for DAPI/FITC/Cy3 (61000v2m, Chroma Technology Corp., Rockingham, VT) and a x40 objective lens (Plan Fluor x40/0.75, Nikon). Microscope control and image acquisition were performed using Image-Pro Plus software (version 6.3, Media Cybernetics, Bethesda, MD). The captured images were analyzed as described previously using our original software (32), 'Tissue Telo', which allows manual identification of nuclear regions from the composite color image: DAPI (blue channel), FITC (green) and Cy3 (red). Fluorescence intensities of telomere signals (Cy3) and centromere signals (FITC) for each nucleus were measured, and then the telomere-centromere ratio (TCR) was calculated, as there is no guarantee that the entire nucleus will be captured within any given tissue section.

IHC staining. The expression of hTERT protein was determined by IHC staining using rabbit antiserum against hTERT prepared by a colleague (O.Y.). It has been confirmed that telomerase activity is included in the immune precipitate obtained with this rabbit antiserum (33). The tissue sections were pre-treated with Tris-EDTA buffer solution $(\mathrm{pH} 9.0)$ at $95^{\circ} \mathrm{C}$. After incubation with the primary antibody for $2 \mathrm{~h}$, visualization was performed using a polymer IHC detection system (Envision Kit, Dako Japan, Kyoto, Japan). The expression of HER2 protein was determined using anti-c-erbB2 antibody (Dako, Glostrup, Denmark) in accordance with the manufacturer's instructions. The degree of HER2 staining was scored as $0,1,2$ or 3 according to the criteria for gastric cancer (34), because there are no established criteria for thyroid cancer, and the staining pattern of thyroid cancer was found to be similar to that of gastric cancer, as described below. The HER2 score was judged by a pathologist (M.K.).

HER2 FISH. We demonstrated HER2 FISH in 3 cases with a HER2 IHC score of 0 or 1 , and in all cases with a HER2 IHC score of 2 or 3. HER 2 FISH was performed using the Histra HER2 FISH kit (Jokoh, Tokyo, Japan), which employs two DNA probes. The probe specific for the HER2 gene was labeled with rhodamine, and an $\alpha$ satellite probe targeting the centromere region of chromosome 17 (CEP17) was labeled with FITC. The assay was performed in accordance with the manufacturer's instructions. In brief, specimens were incubated in pretreatment solution $\left(99^{\circ} \mathrm{C}\right.$ for $\left.20 \mathrm{~min}\right)$ and then digested with protease $\left(37^{\circ} \mathrm{C}\right.$ for $\left.10 \mathrm{~min}\right)$. The DNA probe was applied and hybridized to each section overnight at $37^{\circ} \mathrm{C}$. The slides were then washed, counterstained with DAPI, and observed by fluorescence microscopy. In each of the specimens of papillary carcinoma, the total numbers of HER2 and CEP17 signals were counted in 20 tumor cell nuclei, and the ratios of HER2 signals to CEP17 signals were calculated according to the ASCO/CAP criteria (35). Polysomy 17 was defined as the occurrence of a centromere copy number of three or more for chromosome 17 per cell. 
Statistical analysis. Correlations between HER2 IHC score and FISH ratio were analyzed using the Spearman's rank correlation coefficient. We used an agglomerative hierarchical clustering approach with Ward's method to divide the data for the HER2 FISH ratio into two groups. The significance of differences was examined by TCR with Welch's t-test. The significance of differences in age and tumor size was examined using Student's t-test. The significance of differences in sex, TNM classification and hTERT expression was examined using Fisher's exact probability test. Differences at $\mathrm{P}<0.05$ were considered significant.

\section{Results}

Tissue Q-FISH. Telomere signals (small red spots within nuclei) of tumor cells in papillary carcinoma (Fig. 1A-2 and -4) and follicular tumors were weaker than those in adjacent normal follicular epithelial cells (Fig. 1A-1 and -3). The mean TCR of papillary carcinoma and follicular carcinoma cells was significantly less than that of normal follicular epithelial cells and fibroblasts (Fig. 2, P<0.05). In addition, the mean TCR of follicular carcinoma cells was significantly less than that of papillary carcinoma cells (Fig. 2, $\mathrm{P}<0.05$ ). The peak TCR in papillary carcinoma cells was 1 to 2 , and that in follicular carcinoma cells was close to 1 . The peak TCR in normal follicular epithelial cells was 1.5 to 3.5 , and that in fibroblasts was 2 or more, and the peak TCR in normal follicular epithelial cells and fibroblasts had a very wide distribution (Fig. 2).

hTERT expression. hTERT protein was strongly expressed in the nuclei and nucleoli of cancer cells (Fig. 1B-2). hTERT expression was confirmed not only in cancer cells but also lymphocytes, especially those in lymph follicles. hTERT protein was not expressed in normal follicular epithelial cells (Fig. 1B-1). More than $10 \%$ of tumor cells were considered positive for hTERT expression (Fig. 1B-2). hTERT expres-
Table I. Correlation between HER2 expression and HER2 FISH.

\begin{tabular}{lcc}
\hline & \multicolumn{2}{c}{ FISH ratio } \\
\cline { 2 - 3 } HER2 & $<1.3$ & $\begin{array}{c}\geq 1.3 \\
\text { (protein expression) }\end{array}$ \\
\hline 0 & 3 & 0 \\
(negative, $\mathrm{n}=23)$ & 0 \\
1 & 3 & 4 \\
2 & 13 & 10 \\
\hline
\end{tabular}

sion was detected in all of the follicular carcinomas and in $40(66 \%)$ of the papillary carcinomas.

HER2 status. When the degree of HER2 staining was scored as $0,1,2$ or 3 according to the criteria for gastric cancer, basolateral or lateral cell membranes of papillary carcinoma were strongly stained with a score of 3 (Fig. 1C-4). Seventeen of the papillary carcinomas had an IHC score of 2 and 14 had a score of 3 (Table I). One case of follicular carcinoma had an IHC score of 2, and 2 cases had a score of 3 (data not shown). Amplification of the HER2 gene was confirmed by FISH in cells of differentiated thyroid cancer (Fig. 1D-1, -2 and -3); the HER2 FISH ratio was significantly correlated with the IHC score and FISH ratio (Fig. 3, $\mathrm{P}<0.001$ ). Cluster analysis of the FISH ratio separated the cancers into two groups (showing relative strong and weak amplification), with a borderline of 1.3 (Fig. 3, dotted line). Fourteen of the 32 papillary carcinomas with an IHC score of 2 or 3 showed a FISH ratio of $\geq 1.3$ (Table I). One of the 3 follicular carcinomas with an IHC score of 2 or 3 showed a FISH ratio of $\geq 1.3$ (data not shown). All of the cases with an IHC score of 0 or 1 showed a FISH ratio of $<1.3$ (Fig. 3, Table I). When the cases positive and negative for HER2 amplification were compared, a

Table II. Characteristics of the patients with papillary thyroid carcinoma.

\begin{tabular}{|c|c|c|c|}
\hline & $\begin{array}{l}\text { HER2 IHC 0-1 } \\
\text { or FISH negative }\end{array}$ & FISH positive & P-value \\
\hline Age (average \pm SD) & $51.2 \pm 15.0$ & $47.4 \pm 16.3$ & $0.42^{\mathrm{a}}$ \\
\hline $\begin{array}{l}\text { Sex } \\
\text { Male } \\
\text { Female }\end{array}$ & $\begin{array}{l}10 \\
37\end{array}$ & $\begin{array}{r}4 \\
10\end{array}$ & $0.83^{\mathrm{b}}$ \\
\hline $\begin{array}{l}\text { TNM stage } \\
\text { I-III } \\
\text { IVA }\end{array}$ & $\begin{array}{l}32 \\
15\end{array}$ & $\begin{array}{r}10 \\
4\end{array}$ & $0.55^{\mathrm{b}}$ \\
\hline Tumor size (average \pm SD) & $21.3 \pm 10.2$ & $22.8 \pm 11.6$ & $0.26^{\mathrm{a}}$ \\
\hline TCR (average \pm SD) & $2.6 \pm 1.8$ & $2.3 \pm 1.7$ & $9.20 \times 10^{-10^{c}}$ \\
\hline $\begin{array}{l}\text { hTERT expression } \\
\text { Negative } \\
\text { Positive }\end{array}$ & $\begin{array}{l}19 \\
28\end{array}$ & $\begin{array}{r}2 \\
12\end{array}$ & $0.06^{\mathrm{b}}$ \\
\hline
\end{tabular}

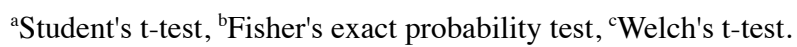



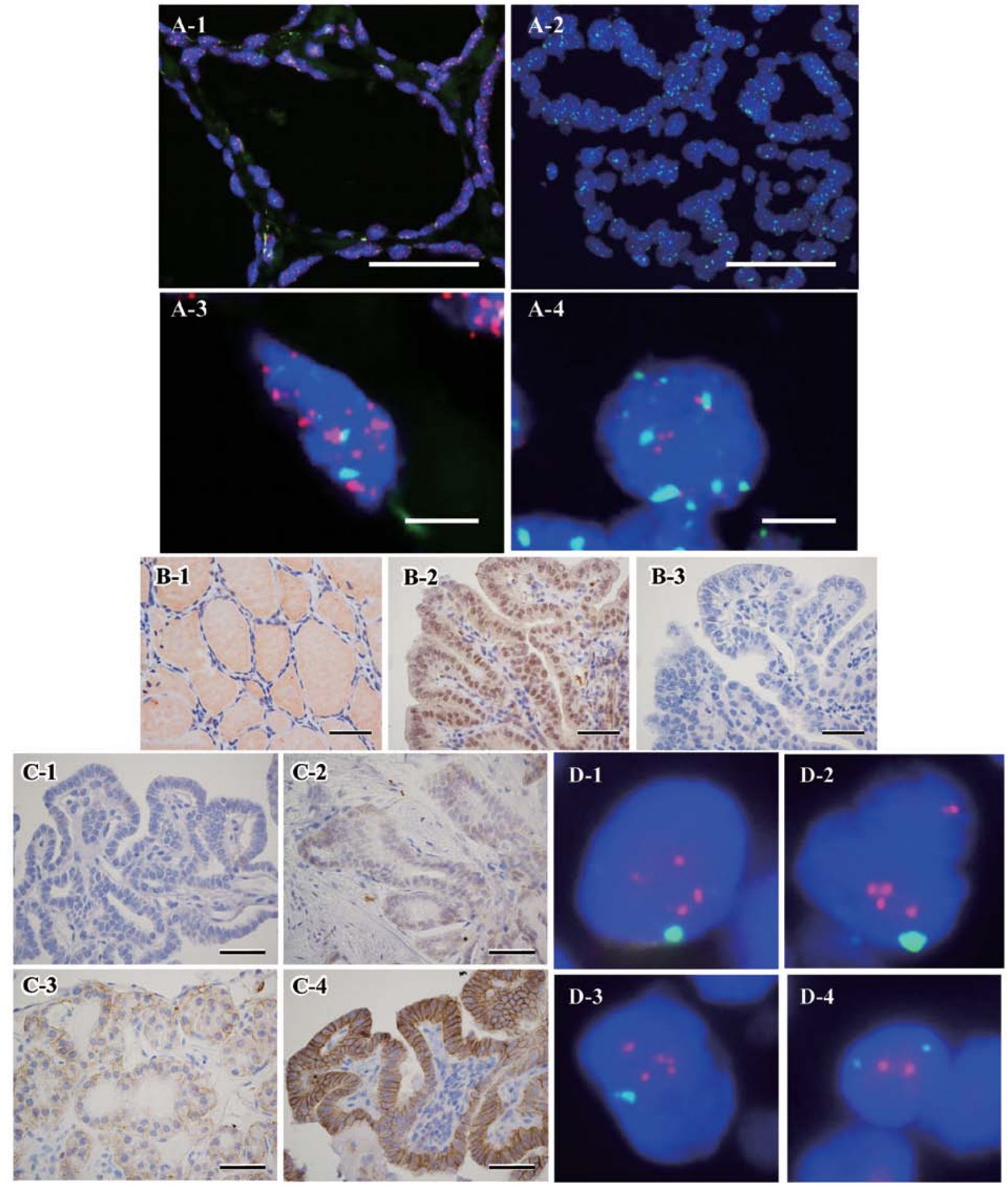

Figure 1. (A) Representative tissue Q-FISH images of normal follicular epithelial cells (A-1 and -3) and papillary carcinomas (A-2 and -4). The nuclei are stained fluorescent blue (DAPI). Red spots (Cy3) and green spots (FITC) within nuclei indicate telomere and centromere signals, respectively. The scale bar is 50 and $5 \mu \mathrm{m}$ in A-1, -2 and A-3, -4 , respectively. Telomere signals of cancer cells are clearly weaker than those in adjacent normal follicular epithelial cells. (B) Immunohistochemical (IHC) staining of follicular epithelial cells (B-1) and papillary carcinomas (B-2) using a polyclonal rabbit antiserum against hTERT. B-3 shows negative control staining against B-2, using rabbit normal serum. The nuclei and nucleoli of cancer cells are stained strongly, but the nuclei of follicular epithelial cells are not stained (scale bars represent $50 \mu \mathrm{m}$ ). (C) HER2 IHC staining of papillary carcinomas. HER2 expression was divided into four depending on staining intensity: score 0 (C-1), no reaction; score 1 (C-2), barely visible (at high magnification); score 2 (C-3), weak staining (at low magnification); score 3 (C-4), strong staining (at low magnification). Lateral and basolateral epithelial cell membranes were stained strongly with a score of 3 (scale bars represent $50 \mu \mathrm{m}$ ). (D) Representative HER2 FISH images of cells with (D-1, -2 and -3) and without (D-4) HER2 gene amplification. Red spots (rhodamine) and green spots (FITC) within nuclei indicate the HER2 gene and CEP17 signals, respectively.

significant difference in mean TCR was observed between them (Table II). Telomeres in the group positive for HER2 amplification were significantly shorter than those in the negative group (Table II). No significant differences in HER2 amplification were observed in terms of age, sex, stage, tumor size and expression of hTERT (Table II). 


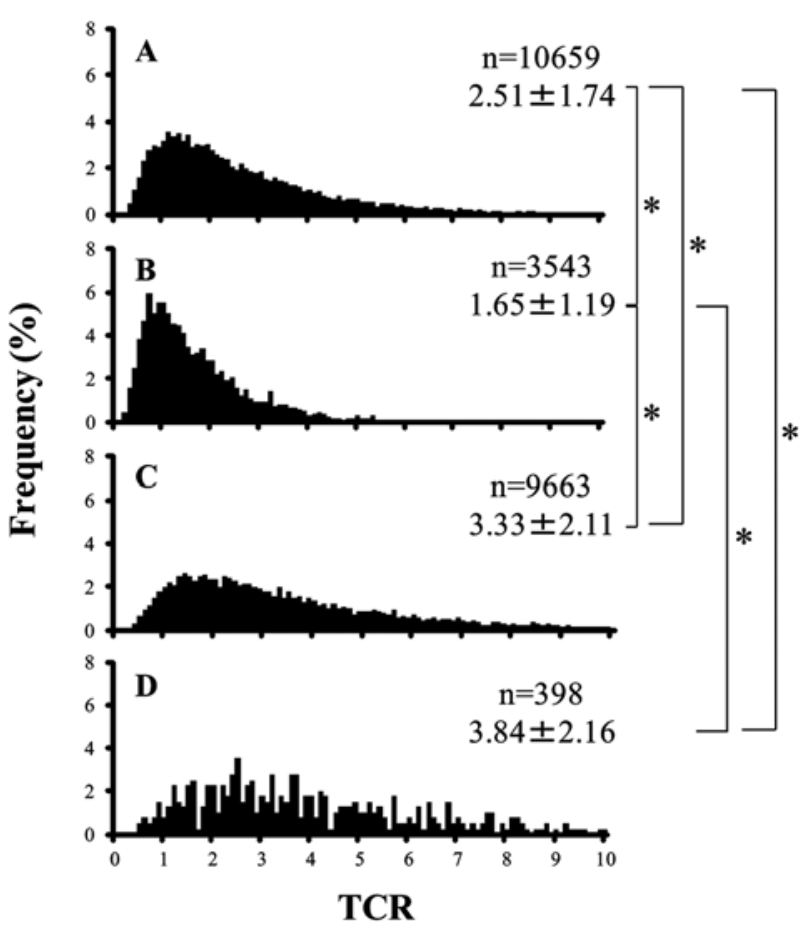

Figure 2. The distribution of TCR in each cell type. (A) Papillary carcinoma, (B) follicular carcinoma, (C) normal follicular epithelial cells, and (D) fibroblasts. Number of analyzed nuclei (n) and mean TCR \pm standard deviation are indicated in each histogram. Asterisks indicate a significant difference. The peak of TCR distribution in A and B was significantly shorter than in C and D.

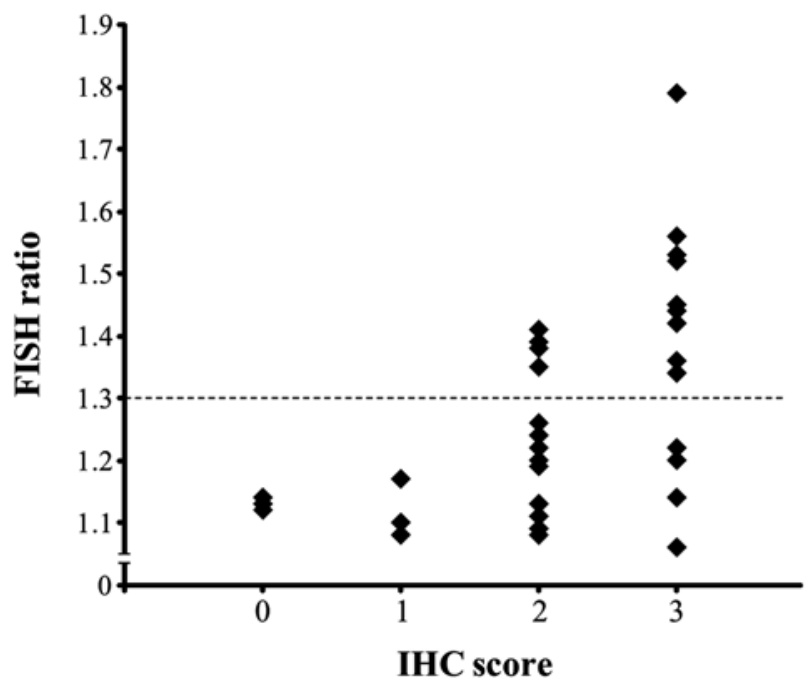

Figure 3. Scatter plot between HER2 IHC score and FISH ratio in papillary carcinomas. There is a very good correlation between the two parameters $(\mathrm{P}<0.001)$.

\section{Discussion}

Papillary carcinoma is the most common form of thyroid malignancy. Although it generally exhibits indolent characteristics and is associated with a favorable prognosis, cases with certain clinicopathological features can be progressive and may have a poor outcome (36). Jonklaas et al reported that the 15-year disease-specific survival of 3572 patients with papillary thyroid cancer was $91 \%$ for males and $96 \%$ for females (37). In a series of investigated 53,856 patients with thyroid cancer, Hundahl et al reported that the 10-year overall survival of those with papillary carcinoma and follicular carcinoma was 93 and $85 \%$, respectively. Thus, follicular carcinoma had a slightly poorer prognosis (38). In the present study, therefore, we examined telomere length, hTERT protein expression and HER 2 amplification status in papillary carcinomas and follicular carcinomas of the thyroid.

Southern blot analysis, which has been widely employed in previous telomere studies has certain problems: although it can measure telomere length in whole cancer tissues including lymphocytes and stem cells, it cannot exclude the subtelomere components (32). In the present study, therefore, we employed tissue Q-FISH method for determination of telomere length. We have developed a much more accurate Q-FISH-based method that can effectively estimate telomere length in different cell types using separate PNA probes for telomeres and centromeres. Tissue Q-FISH is able to measure the telomere length of cancer cells precisely, and here we obtained the telomere-centromere ratio (TCR) as a parameter representative of the telomere length. The centromere is an accurate internal control parameter, and the TCR has been shown in many previous studies to accurately reflect telomere length $(31,32,39)$. Using Southern blot analysis, we have already shown that the telomere length of differentiated thyroid cancer cells is shorter than that in adjacent normal tissue (27). In the present study, the mean TCR of cancer cells was significantly less than that of normal follicular cells. In addition, the peak frequency of TCR for papillary carcinomas and follicular carcinomas was 1 to 2 and near 1, respectively. The TCR of normal cells had a wide distribution. Using tissue Q-FISH, Kammori et al (32) and Kurabayashi et al (39) previously investigated telomere length in esophageal and breast cancers, respectively. They found that the TCR distribution was very similar to that in our present study, the peak TCR frequency being $<1$ for cancer cells and $>1$ for adjacent normal cells, and the TCR for normal cells showing a wide distribution. The telomeres of follicular carcinoma, which has poorest prognosis among differentiated thyroid cancers, were shorter than those of papillary carcinoma. Therefore, measurement of telomere length using tissue Q-FISH appears to be useful for assessment of malignant potential. To our knowledge, this is the first report to have documented the use of tissue Q-FISH for analysis of telomere length in thyroid cancers.

For detection of hTERT protein, strong staining of nuclei and nucleoli was demonstrated by IHC. In addition, hTERT protein was recognized in lymphocytes as well as thyroid cancer cells. Using in situ hybridization (ISH), Kammori et al examined the expression of hTERT mRNA in colorectal carcinomas and follicular thyroid carcinomas, and found a pattern similar to that in the present study $(24,30)$. hTERT protein was detected in $66 \%$ and $100 \%$ of papillary and follicular carcinomas, respectively. In a previous study, we examined the telomerase activity of thyroid cancer using TRAP, and found that papillary carcinomas and follicular carcinomas 
were positive in 87.5 and $100 \%$ of cases, respectively (27). These results suggested that the expression of hTERT protein was related to the malignant potential of thyroid cancers.

There are two established techniques for monitoring HER2 status: gene amplification detected by fluorescence in situ hybridization (FISH) and protein overepression detected by IHC. Early studies indicated that there was a close correlation between the data obtained by these two methods. In a series of 2279 patients with breast cancer, Lal et al found that FISH data were correlated with an IHC score of 0,1 or 3 , whereas only $25 \%$ of cases with an IHC score of 2 demonstrated gene amplification by FISH (40). On the other hand, Kammori et al have reported that detection of HER2 protein expression using IHC was not satisfactory for evaluation of HER2 status in breast cancer, because a number of cases showing discrepancy between IHC and FISH data were found (41). The present study revealed a significant correlation between IHC score and the FISH ratio. As the IHC staining characteristics of thyroid cancer were very similar to those of gastric cancer (lateral and basolateral epithelial cell membranes being strongly stained), we used the IHC scoring criteria for gastric cancer in this study. In cases of breast and gastric cancer, HER 2 amplification is considered positive when FISH demonstrated a ratio of $\geq 2.0$, but none of our present specimens of thyroid cancer attained this value. However, FISH would theoretically show a ratio of 1.0 for normal cells showing no HER2 gene amplification. Despite the low frequency of HER2 gene amplification, it is thought to be certainly present in thyroid cancer cells. When we performed cluster analysis of the HER2 FISH ratio, we were able to divide the cases into two groups, one showing strong amplification (FISH ratio $\geq 1.3$ ) and the other showing weak amplification (FISH ratio $<1.3$ ); $23 \%$ of papillary carcinomas showed strong amplification. The HER2 positivity rate has been reported to be around $25 \%$ in breast cancers and $15-25 \%$ in gastric cancers $(3,4,6-9)$, and that for thyroid cancer was considered to be proportional to FISH ratio of 1.3 . HER2-positive cases of breast and gastric cancer are known to have a poor prognosis (3-5,7,9-14). Positivity for HER2 gene amplification was considered to be an indicator of poor prognosis in thyroid cancer, because papillary carcinomas with a HER2:FISH ratio of $\geq 1.3$ had short telomeres and high malignant potential. Although some studies have tried to detect gene amplification and/or protein overexpression of HRE2 in thyroid cancer, they did not involve detailed examination of the FISH ratio (42-46). To our knowledge, this is the first reported study to have examined the HER2 status of thyroid cancer in detail.

Thyroid cancer generally exhibits indolent behavior and has a good prognosis (36-39). Many previous studies have suggested that short telomeres in cancer tissues are a negative prognostic indicator (47-52). In the present study, papillary carcinomas, which have a relatively good prognosis, maintained their telomere lengths and had a low rate of positivity for hTERT protein in comparison with follicular carcinomas, suggesting that measurement of telomere length by tissue Q-FISH and expression of hTERT protein using IHC would be useful for indicating the malignant potential of thyroid cancer. It was also suggested that HER2 status might have an important prognostic impact in thyroid cancer, as is the case for breast cancer and gastric cancer, because in the present series, cancers with marked HER2 gene amplification had short telomeres. When we applied the HER2 amplification criteria for breast and gastric cancer strictly to thyroid cancer, all of cases examined were judged as negative. However, the low frequency of HER2 gene amplification may not be surprising when considering that thyroid cancer exhibits indolent characteristics and very slow growth.

Currently, there is no effective chemotherapy for differentiated thyroid cancer, and radiation therapy using 131I is common in a postoperative adjuvant setting. If HER2 positivity can be detected in thyroid cancer, it may be possible to try alternative therapies such as trastuzumab for patients with intractable thyroid cancer that does not respond to radiation therapy.

In summary, the present study has identified amplification of the HER2 gene and/or overexpression of HER2 protein in approximately $23 \%$ of human papillary thyroid carcinomas, and shown that the telomeres of HER2-positive cancers are shorter than those of negative cancers. These results suggest that highly malignant thyroid cancer can be detected by monitoring HER2 status and telomere length, and that trastuzumab therapy may be effective for patients with advanced thyroid cancer.

\section{Acknowledgements}

We would like to thank Dr Mitsuyoshi Hirokawa (Kuma Hospital) for pathological diagnosis, and Miyoko Matsumoto (Kanaji Hospital) for assistance with preparation of the manuscript.

\section{References}

1. Hynes NE and Stern DF: The biology of erbB-2/neu/HER-2 and its role in cancer. Biochim Biophys Acta 1198: 165-184, 1994.

2. Akiyama T, Sudo C, Ogawara H, Toyoshima K and Yamamoto T: The product of the human c-erbB-2 gene: a 185-kilodalton glycoprotein with tyrosine kinase activity. Science 232: 1644-1646, 1986.

3. Salmon DJ, Clark GM, Wong SG, Levin WJ, Ullrich A and McGuire WL: Human breast cancer: correlation of relapse and survival with amplification of the HER-2/neu oncogene. Science 235: 177-182, 1987.

4. Salmon DJ, Godolphin W, Jones LA, Holt JA, Wong SG, Keith DE, Levin WJ, Stuart SG, Udove J, Ullrich A and Press MF: Studies of the HER-2/neu proto-oncogene in human breast and ovarian cancer. Science 244: 707-712, 1989.

5. Ross JS and Fletcher JA: The HER-2/neu oncogene in breast cancer: prognostic factor, predictive factor, and target for therapy. Oncologist 3: 237-252, 1998.

6. Hofmann M, Stoss O, Shi D, Büttner R, van de Vijver M, Kim W, Ochiai A, Rüschoff J and Henkel T: Assessment of a HER2 scoring system for gastric cancer: results from a validation study. Histopathology 52: 797-805, 2008.

7. Park DI, Yun JW, Park JH, Oh SJ, Kim HJ, Cho YK, Shon CI, Jeon WK, Kim BI, Yoo CH, Son BH, Cho EY, Chae SW, Kim EJ, Shon JH, Ryu SH and Sepulveda AR: HER-2/neu amplification is an independent prognostic factor in gastric cancer. Dig Dis Sci 51: 1371-1379, 2006.

8. Yano T, Doi T, Ohtsu A, Boku N, Hashizume K, Nakanishi M and Ochiai A: Comparison of HER2 gene amplification assessed by fluorescence in situ hybridization and HER2 protein expression assessed by immunohistochemistry in gastric cancer. Oncol Rep 15: 65-71, 2006.

9. Zhag XL, Yang YS, Xu DP, Qu JH, Guo MZ, Gong Y and Huang J: Comparative study on overexpression of her $2 /$ neu and her3 in gastric cancer. World J Surg 33: 2112-2118, 2009.

10. Uchino S, Tsuda H, Maruyama K, Kinoshita T, Sasako M, Saito T, Kobayashi M and Hirohashi S: Overexpression of c-erbB-2 protein in gastric cancer. Its correlation with long-term survival of patients. Cancer 72: 3179-3184, 1993. 
11. Nakajima M, Sawada H, Yamada Y, Watanabe A, Tatsumi M, Yamashita J, Matsuda M, Sakaguchi T, Hirano T and Nakano H: The prognostic significance of amplification and overexpression of c-met and c-erb B-2 in human gastric carcinomas. Cancer 85: 1894-1902, 1999.

12. Allgayer $\mathrm{H}$, Babic R, Gruetzner KU, Tarabichi A, Schildberg FW and Heiss MM: c-erbB-2 is of independent prognostic relevance in gastric cancer and is associated with the expression of tumor-associated protease systems. J Clin Oncol 18: 2201-2209, 2000

13. Garcia I, Vizoso F, Martin A, Sanz L, Abdel-Lah O, Raigoso P and García-Muñiz JL: Clinical significance of the epidermal growth factor receptor and HER2 receptor in resectable gastric cancer. Ann Surg Oncol 10: 234-241, 2003.

14. Tanner M, Hollmén M, Junttila TT, Kapanen AI, Tommola S, Soni Y, Helin H, Salo J, Joensuu H, Sihvo E, Elenius K and Isola J: Amplification of HER-2 in gastric carcinoma: association with topoisomerase IIalpha gene amplification, intestinal type, poor prognosis and sensitivity to trastuzumab. Ann Oncol 16: $273-278,2005$

15. Bang YJ, Van Cutsem E, Feyereislova A, Chung HC, Shen L, Sawaki A, Lordick F, Ohtsu A, Omuro Y, Satoh T, Aprile G, Kulikov E, Hill J, Lehle M, Rüschoff J and Kang YK: ToGA Trial Investigators: Trastuzumab in combination with chemotherapy versus chemotherapy alone for treatment of HER2-positive advanced gastric or gastro-oesophageal junction cancer (ToGA): a phase 3, open-label, randomised controlled trial. Lancet 376: 687-697, 2010.

16. Blackburn EH: Structure and function of telomeres. Nature 350: 569-573, 1991.

17. Harley CB, Futcher AB and Greider CW: Telomeres shorten during ageing of human fibroblasts. Nature 345: 458-460, 1990.

18. Von Zglinicki T: Oxidative stress shortens telomeres. Trends Biochem Sci 27: 339-344, 2002.

19. Harly CB and Villeponteau B: Telomeres and telomerase in aging and cancer. Curr Opin Genet Dev 5: 249-255, 1995.

20. De Lange T: Telomeres and senescence: ending the debate. Science 279: 334-335, 1998.

21. DePinho RA: The age of cancer. Nature 408: 248-254, 2000.

22. Svenson U and Roos G: Telomere length as a biological marker in malignancy. Biochim Biophys Acta 1792: 317-323, 2009.

23. Wyatt HD, West SC and Beattie TL: InTERTpreting telomerase structure and function. Nucleic Acids Res 38: 5609-5622, 2010.

24. Kammori M, Nakamura K, Hashimoto M, Ogawa $T$, Kaminishi $\mathrm{M}$ and Takubo K: Clinical application of human telomerase reverse transcriptase gene expression in thyroid follicular tumors by fine-needle aspirations using in situ hybridization. Int J Oncol 22: 985-991, 2003.

25. Furugori E, Hirayama R, Nakamura K, Kammori M, Esaki Y and Takubo K: Telomere shortening in gastric carcinoma with aging despite telomerase activation. J Cancer Res Clin Oncol 126: 481-485, 2000 .

26. Nakamura K, Furugori E, Esaki Y, Arai T, Sawabe M, Okayasu I, Fujiwara M, Kammori M, Mafune K, Kato M, Oshimura M, Sasajima K and Takubo K: Correlation of telomere lengths in normal and cancers tissue in the large bowel. Cancer Lett 158 : $179-184,2000$

27. Kammori M, Takubo K, Nakamura K, Furugouri E, Endo H, Kanauchi H, Mimura Y and Kaminishi M: Telomerase activity and telomere length in benign and malignant human thyroid tissues. Cancer Lett 159: 175-181, 2000.

28. O'Sullivan JN, Bronner MP, Brentnall TA, Finley JC, Shen WT, Emerson S, Emond MJ, Gollahon KA, Moskovitz AH, Crispin DA, Potter JD and Rabinovitch PS: Chromosomal instability in ulcerative colitis is related to telomere shortening. Nat Genet 32: 280-284, 2002

29. Meeker AK, Gage WR, Hicks JL, Simon I, Coffman JR, Platz EA, March GE and De Marzo AM: Telomere length assessment in human archival tissues: combined telomere fluorescence in situ hybridization and immunostaining. Am J Pathol 160: 1259-1268, 2002.

30. Kammori M, Kanauchi H, Nakamura K, Kawahara M, Weber TK, Mafune K, Kaminishi M and Takubo K: Demonstration of human telomerase reverse transcriptase in human colorectal carcinomas by in situ hybridization. Int J Oncol 20: 15-21, 2002

31. Aida J, Izumiyama-Shimomura N, Nakamura K, Ishii A, Ishikawa N, Honma N, Kurabayashi R, Kammori M, Poon SS Arai $\mathrm{T}$ and Takubo $\mathrm{K}$ : Telomere length variations in 6 mucosal cell types of gastric tissue observed using a novel quantitative fluorescence in situ hybridization method. Hum Pathol 38 1192-1200, 2007.
32. Kammori M, Izumiyama N, Nakamura K, Kurabayashi $\mathrm{R}$, Kashio M, Aida J, Poon SS and Kaminishi M: Telomere metabolism and diagnostic demonstration of telomere measurement in the human esophagus for distinguishing benign from malignant tissue by tissue quantitative fluorescence in situ hybridization. Oncology 71: 430-436, 2006.

33. Kawauchi K, Ihjima K and Yamada O: IL-2 increases human telomerase reverse transcriptase activity transcriptionally and posttranslationally through phosphatidylinositol 3'-kinase/Akt, heat shock protein 90, and mammalian target of rapamycin in transformed NK cells. J Immunol 174 5261-5269, 2005.

34. Rüschoff J, Dietel M, Baretton G, Arbogast S, Walch A, Monges G, Chenard MP, Penault-Llorca F, Nagelmeier I, Schlake W, Höfler H and Kreipe HH: HER2 diagnostics in gastric cancer-guideline validation and development of standardized immunohistochemical testing. Vichows Arch 457: 299-307, 2010.

35. Wolff AC, Hammond ME, Schwartz JN, Hagerty KL, Allred DC, Cote RJ, Dowsett M, Fitzgibbons PL, Hanna WM, Langer A, McShane LM, Paik S, Pegram MD, Perez EA, Press MF, Rhodes A, Sturgeon C, Taube SE, Tubbs R, Vance GH, van de Vijver M, Wheeler TM and Hayes DF: American Society of Clinical Oncology/College of American Pathologists guideline recommendations for human epidermal growth factor receptor 2 testing in breast cancer. J Clin Oncol 25: 118-145, 2007.

36. Ito Y, Fukushima M, Kihara M, Takamura Y, Kobayashi K, Miya A and Miyauchi A: Investigation of the prognosis of patients with papillary thyroid carcinoma by tumor size. Endocr J 59: 457-464, 2012.

37. Jonklaas J, Nogueras-Gonzalez G, Munsell M, Litofsky D, Ain KB, Bigos ST, Brierley JD, Cooper DS, Haugen BR, Ladenson PW, Magner J, Robbins J, Ross DS, Skarulis MC, Steward DL, Maxon HR and Sherman SI: The impact of age and gender on papillary thyroid cancer survival. J Clin Endocrinol Metab 97: E878-E887, 2012.

38. Hundahl SA, Fleming ID, Fremgen AM and Menck HR: A national cancer data base report on 53,856 cases of thyroid carcinoma treated in the U.S., 1985-1995. Cancer 83: 2638-2648, 1998.

39. Kurabayashi R, Takubo K, Aida J, Honma N, Poon SS, Kammori M, Izumiyama-Shimomura N, Nakamura K, Tsuji E, Matsuura M, Ogawa T and Kaminishi M: Luminal and cancer cells in the breast show more rapid telomere shortening than myoepithelial cells and fibroblasts. Hum Pathol 39: 1647-1655, 2008.

40. Lal P, Salazar PA, Hudis CA, Ladanyi M and Chen B: HER-2 testing in breast cancer using immunohistochemical analysis and fluorescence in situ hybridization: a single-institution experience of 2,279 cases and comparison of dual-color and single-color scoring. Am J Clin Pathol 121: 631-636, 2004.

41. Kammori M, Kurabayashi R, Kashio M, Sakamoto A, Yoshimoto M, Amano S, Kaminishi M, Yamada T and Takubo K: Prognostic utility of fluorescence in situ hybridization for determining HER2 gene amplification in breast cancer. Oncol Rep 19: 651-656, 2008.

42. Kremser R, Obrist P, Spizzo G, Erler H, Kendler D, Kemmler G, Mikuz $\mathrm{G}$ and Ensinger C: Her2/neu overexpression in differentiated thyroid carcinomas predicts metastatic disease. Virchows Arch 442: 322-328, 2003.

43. Mondi MM, Rich R, Ituarte P, Wong M, Bergman S, Clark OH and Perrier ND: HER2 expression in thyroid tumors. Am Surg 69: 1100-1103, 2003

44. Ensinger C, Prommegger R, Kendler D, Gabriel M, Spizzo G, Mikuz G and Kremser R: Her2/neu expression in poorlydifferentiated and anaplastic thyroid carcinomas. Anticancer Res 23: 2349-2354, 2003

45. Freudenberg LS, Sheu S, Görges R, Mann K, Bokler S, Frilling A, Schmid KW, Bockisch A and Otterbach $\mathrm{F}$ : Prognostic value of c-erbB-2 expression in papillary thyroid carcinoma. Nuklearmedizin 44: 179-184, 2005.

46. Mitteldorf CA, Leite KR, Meirelles MI, Gattas GJ and Camara-Lopes LH: Overexpression of HER2/neu oncoprotein in cytologic specimens. Acta Cytol 48: 199-206, 2004.

47. Griffith JK, Bryant JE, Fordyce CA, Gilliland FD, Joste NE and Moyzis RK: Reduced telomere DNA content is correlated with genomic instability and metastasis in invasive human breast carcinoma. Breast Cancer Res Treat 54: 59-64, 1999. 
48. Fordyce CA, Heaphy CM, Bisoffi M, Wyaco JL, Joste NE, Mangalik A, Baumgartner KB, Baumgartner RN, Hunt WC and Griffith JK: Telomere content correlates with stage and prognosis in breast cancer. Breast Cancer Res Treat 99: 193-202, 2006.

49. Heaphy CM, Baumgartner KB, Bisoffi M, Baumgartner RN and Griffith JK: Telomere DNA content predicts breast cancer-free survival interval. Clin Cancer Res 13: 7037-7043, 2007.

50. Donaldson L, Fordyce C, Gilliland F, Smith A, Feddersen R, Joste N, Moyzis R and Griffith J: Association between outcome and telomere DNA content in prostate cancer. J Urol 162: 1788-1792, 1999.
51. Fordyce CA, Heaphy CM, Joste NE, Smith AY, Hunt WC and Griffith JK: Association between cancer-free survival and telomere DNA content in prostate tumors. J Urol 173: 610-614, 2005.

52. Frías C, García-Aranda C, De Juan C, Morán A, Ortega P, Gómez A, Hernando F, López-Asenjo JA, Torres AJ, Benito M and Iniesta P: Telomere shortening is associated with poor prognosis and telomerase activity correlates with DNA repair impairment in non-small cell lung cancer. Lung Cancer 60: 416-425, 2008 